\title{
Heritage envelope refurbishment to manage OTTV, RTTV and preservation: The case of Sirinthorn building of Rajavithi Hospital, Bangkok
}

\author{
Waranyoo Siriwan ${ }^{1}$ \\ ${ }^{1}$ Phranakorn Rajabhat University, Thailand, waranyoo@pnru.ac.th
}

\begin{abstract}
This paper aims to reflect the refurbishment concept for a heritage building envelope for energy conservation, in particular decreasing the thermal transfer by material application. The Sirinthorn building, a heritage hospital in Bangkok is discussed as a case study which focuses on two main issues - thermal transfer by concepts that are consistent with the hospital building renovation rules, and the improvement of the conservation architecture. Factors influencing the framework include building location and environment, local regulations, an existing interior function, the materials selection concept, building shape and its identity, and conservation guidelines related to an area. The methodology is implemented by investigating the Overall Thermal Transfer Value (OTTV) and Roof Thermal Transfer Value (RTTV) from the existing envelope, in addition to "trial and error in the selection of parameters for the heat insulation properties of industrial materials.

The research output offers an optional model for the envelope refurbishment for the Sirinthorn renovation project where the effect from surrounding is discussed. The envelope is refurbished cooperatively between annexing interior insulation and restoring heritage external surfaces. Its result not only reduces the OTTV and RTTV of the case study below that of the Thai energy code, but also conserves the heritage character of the building. The outcome demonstrates the option for the use of opaque and transparent materials with properties both to save energy, internal outcome to patient zone and provide architectural conservation.
\end{abstract}

Key words: Architectural envelope, Heritage Refurbishment, A hospital in Bangkok, Overall Thermal Transfer

\section{INTRODUCTION}

As anaverage temperature in Bangkok is increased and prolonged in summer, by climate change, it results in hospital buildings over consuming electrical energy to preserve a comfortable temperature in the interior air-conditioned zone next to the envelope area. This situation has trended gradually upwards, in particular the heritage hospitals where constructed 25-50 years ago, are confronting the problem to control the heat transfer from outdoors into the building interior. Their components and equipment are different from new or recent construction projects. The new projects are constructed with new energy saving technology but heritage buildings did not have this.

Besides the obsolete equipment, the major issue is the form and design of the hospital building envelope and the physical properties (and condition) of the construction materials and components also affecting performance[1].The old envelope cannot control heat transfer, but is valuable to conserve the historical background. Namely, it is recognized that the external envelope plays a major role in determining the aesthetic quality of the building exterior in its form, color, texture and cultural associations [2]

Envelope renovations are concerned to the physical and aesthetic changes to the building. The physical view focused on energy-related by improving building OTTV/ RTTV. The other is the conservation by changing building aesthetic and functionality that may induce or include energy related improvements [3].The typical hospital renovations have seldom realized on the energy saving and architectural historic character preservation. This has resulted in previous renovations conflicting the existing architectural character and not saving energy.

\subsection{Building overall thermal transfer management, Thai} regulation and heritage conservation.

Building overall thermal transfer management aims to save energy and promote building energy efficiency. One accepted theory is the 'green building' proposing the creation of healthier and more resource efficient models of construction, renovation, operation and maintenance[4]. The theory is applied in LEED (Leadership in Energy and Environmental Design) to assess energy conservation for all building categories mentioned in the section of Energy and Atmosphere (EA). One important key in LEED to achieve building thermal transfer management is OTTV (Overall Thermal Transfer values) and RTTV (Roof Thermal Transfer values), related to heat gain in buildings. Heat gain effects on the cooling load building design and energy consumption in the building OTTV [5]. OTTV, RTTV are defined the rate of heat transfer through building walls and windows (for OTTV), and RTTV is done for roofs and skylights. OTTV and RTTV act as an index for comparing the thermal performance 
of buildings [6]. It can be estimated from the total rate of heat transfer through envelope per a square meter as the equation (1) [7] and equation (2) [8] below:

$$
\begin{gathered}
\text { OTTV }=\frac{Q w c+Q g c+Q g s}{A w+A f}= \\
\frac{(A w * U w * T D e q)+(A f * U f * T D e q)+A f * S C * S F)}{A w+A f}(1)
\end{gathered}
$$

RTTV =

$\mathrm{Uf}(1-\mathrm{RSR}) \mathrm{TDeq}-\mathrm{Urf}(\mathrm{RSR}) \Delta T+(R S R)(S F)(S C)$

Where $\mathrm{Q}_{\mathrm{wc}}$ is rate of heat transfer through conduction through opaque walls, $\mathrm{Q}_{\mathrm{gs}}$ is rate of heat transfer through solar radiation through window glass, $\mathrm{Q}_{\mathrm{gc}}$ is a glass conduction term, $A_{w}$ and $A_{f} i s$ wall and window area. Where $A_{w}, A_{f}$ are wall and window area $\left(\mathrm{m}^{2}\right), \mathrm{U}_{\mathrm{w}}$ and $\mathrm{U}_{\mathrm{f}}$ are $\mathrm{U}$-values of walls and windows $\left(\mathrm{Wm}^{-2} \mathrm{~K}^{-1}\right), \mathrm{TD}_{\mathrm{eq}}$ is equivalent Temperature Difference (K), SC is Shading Coefficient of window glass, $\mathrm{SF}$ is a solar factor $\left(\mathrm{Wm}^{-2}\right)$ and RSR is a skylight ration of roof (the skylight area/gross area of the roof)

Later LEED was adopted in Thailand to campaigned energy saving in building. It is called 'the regulation of minimum requirement of thermal transfer values' assigned by PCD (Pollution Control Department)[9]. The regulation content prescribes that the building, its area of air-conditioning zone is exceed 2,000 square meters, is required to declare OTTV and RTTV. This regulation classifies the building according to the usage characteristics with maximum requirement of OTTV and RTTV in watts per square meter as shown in Table 1.The case of Sirinthorn is categorized as a hospital type, so the minimum requirement of OTTV and RTTV must not exceed 30 and 10 watts per square meter.

Table 1:The minimum standard of OTTV and RTTV requirement by building categories in Thailand.(Pollution Control Department, Ministry of Natural Resources and Environment., 2010)

\begin{tabular}{|l|c|c|}
\hline Building categories & $\begin{array}{c}\text { Maximum } \\
\text { requirement of } \\
\text { OTTV } \\
\text { (Watts /square } \\
\text { meter.) }\end{array}$ & $\begin{array}{c}\text { Maximum } \\
\text { requirement of } \\
\text { RTTV } \\
\text { (Watts /square } \\
\text { meter.) }\end{array}$ \\
\hline $\begin{array}{l}\text { Education institutions, Office } \\
\text { buildings }\end{array}$ & $\mathbf{5 0}$ & $\mathbf{1 5}$ \\
\hline $\begin{array}{l}\text { Theatres, Shopping malls, } \\
\text { Department } \\
\text { Entertainment sports, Halls, } \\
\text { auditoriums }\end{array}$ & $\mathbf{4 0}$ & $\mathbf{1 2}$ \\
\hline $\begin{array}{l}\text { Hotel, Resorts, Hospitals, } \\
\text { Apartment and condominium } \\
\text { units. }\end{array}$ & $\mathbf{3 0}$ & $\mathbf{1 0}$ \\
\hline
\end{tabular}

The OTTV and RTTV code standards offer a science-based target for building thermal properties, whereas heritage conservation aims to preserve historical building information. Referring to the principle of ICOMOS (International Council on Monuments and Sites), it states that the method of building conservation which is divided in preservation, maintenance, restoration, reconstruction and adaptation [10], [11]. ICOMOS focuses on archaeological site where is older than 100 years and useful in art history or archaeology. However, in a case of 25-30 years old hospitals are recorded by the
DOCOMOMO International party which focus on preparing documents and exchange appropriate conservation practices in modern architecture [12].

In Thailand, DOCOMOMO and ICOMOS coordinate Fine Arts Department (FAD) is responsible for protecting and conserving cultural heritage. To achieve a holistic renovation, the implementation correspond independently by local bounds both energy efficiency (OTTV management) and the method of heritage conservation within its environment[13] and the local regulation.

\subsection{Assumption}

The research assumption is that the heritage preservation effort of cultural value in the heritage building can alongside implement with efficiency of OTTV, RTTV management by control the variables related to the building parameters-an interior function, lighting and temperature, environment such as location and a sun path. They are under control of the standard regulation of OTTV, RTTV requirement in Thailand and the hospital management committees' policy as presented in Figure 1. So the dependent output is expected to the material application for energy saving for building envelope system to balance promoting OTTV, RTTV status under the Thailand code and fully preserving the heritage value without depreciation its existing character.

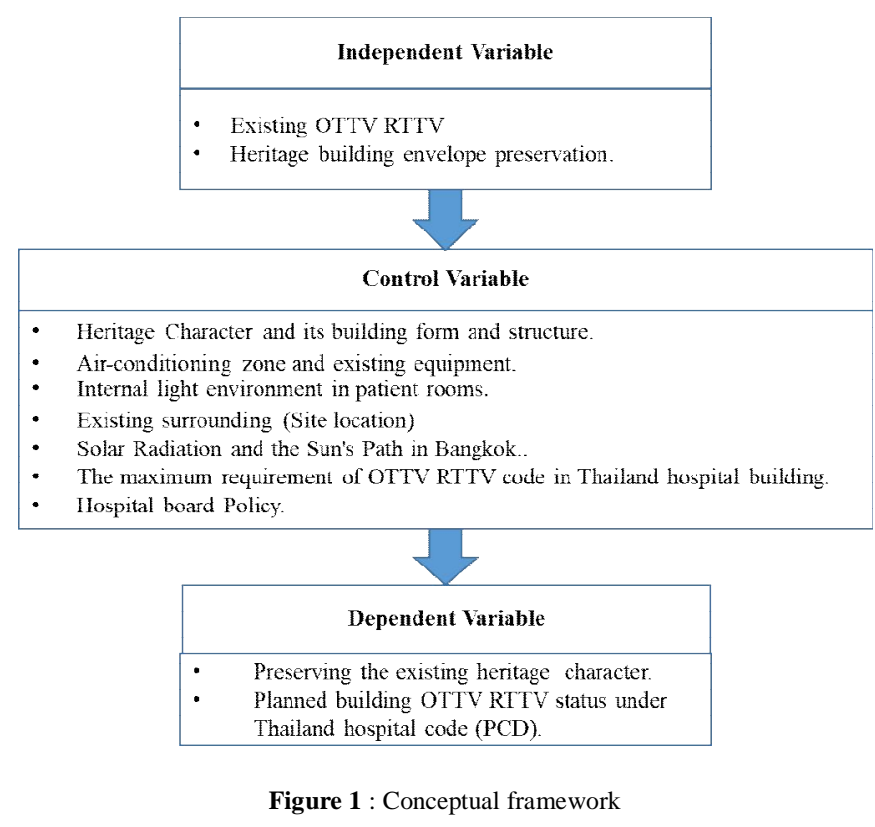

\section{BUILDING INFORMATION AND METHODS}

\subsection{Building Information and surrounding}

The case of Sirinthorn is the historic healthcare building locates in the Bangkok urban area, Figure 3 shows the existing environment of the Sirinthorn building where many buildings surround. The most adjacent buildings are taller than the case study, except two buildings on the southern east direction. Figure 4 shows building shade analysis by the 3D simulation model referred to the Geographic north correlated to an azimuth angle of Bangkok location during a day in the summer (March and April). The result of simulation in Figure 
4 , it founds that the building case receives the full sunlight from the morning until $2 \mathrm{pm}$. But after then, the shade of taller west buildings cover the case study building from the whole sunny direction along the afternoon.

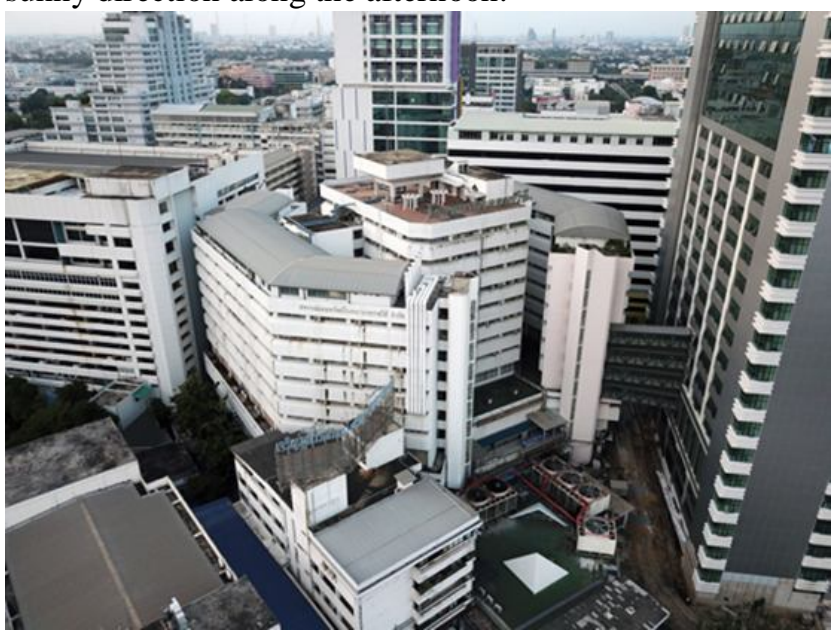

Figure 2: The case study building and its surrounding. (DOCOMOMO Thailand. 2019.)

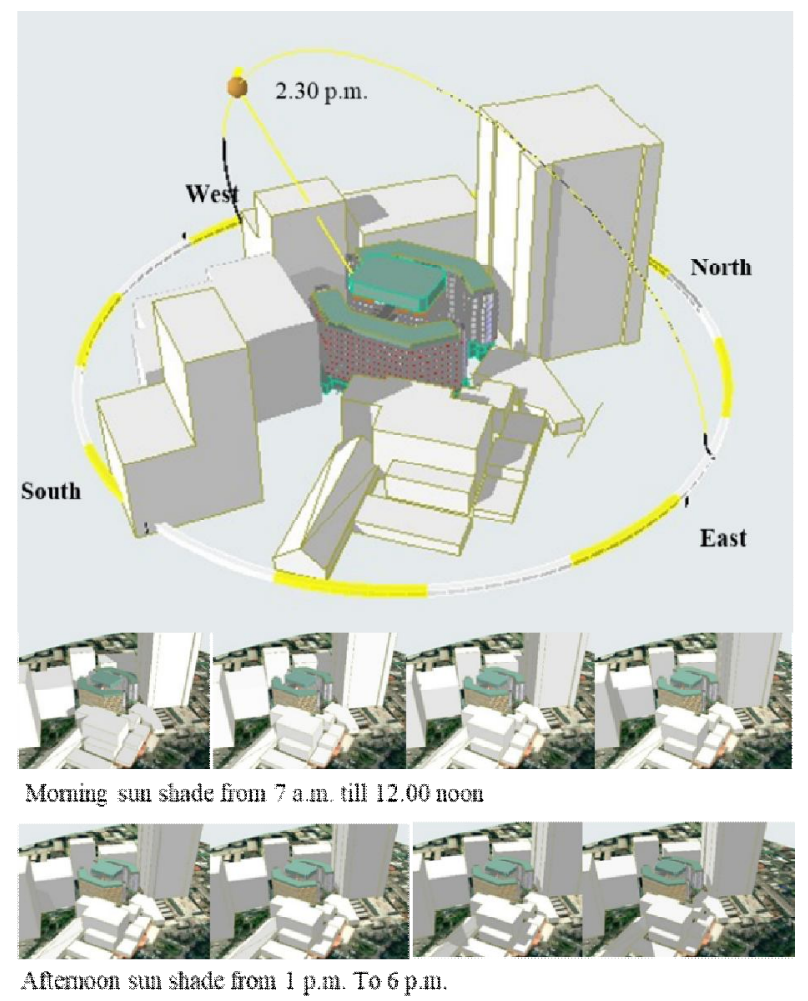

Figure 3: The building shading analysis with the true northin Bangkok by ArchiCAD

A plan, sections and elevation

This research surveys the existing building envelope of the old hospital, which its committee board proposes to improve. The case of Sirinthorn, a hexagon-shaped building, consists of 12 -storeys that combines various medical functions. The specific area scope is the ward of in-patient units and medical offices where is next to the building envelope, on the fourth to the tenth floor as shown in the building plan and sections,
Figure 4 and. Figure 5. The case study has a total floor area of $16,063.534$ square meters. The area is composed of the medical offices at one main core building $(6,268.93$ square meters) and two enclosing wings (6,268.93 square meters).

Figure 4 shows the summary of whole opaque and transparent area of each direction facade and roof by number, as Table 2concludesthe existing whole envelope component details- their names, material description, category, component thickness and areas. The component composes of 3 material type- brick wall with 2-side rendered,concrete floor slabs, and the clear float glass panel of windows. The whole building section in Figure 6describes the heights of the case (approximately 37 meters), the height between floors (3.50 meters),the clearance distance both between the Sirinthorn building and the adjacent buildings and within the case (the medical offices to the inpatients' rooms).Figure 5 also shows the effect of sunlight past the envelope into the interior that is the effect by facade form (the elevations in Figure 6), there are (A) the southeast elevation and (B) Northeast elevation illustrating the shadow effect in the afternoon ( $2 \mathrm{pm}$.), and it found that it is quite shady.

\section{Existing components in building walls and roofs}

The material database from surveying of the existing envelope component is inputted to BEC to calculate; the data are separated into two classes: opaque (walls and roofs), transparent. Table 3 shows the summary of the existing opaquecomponents in Walls and roof presents $\mathrm{Q}_{\mathrm{wc}}$ calculated by the value of $U_{w}, D S H$, Solar Absorbance, $T_{\text {Deq }}$ is constant in each wall area. The constructed materials are a solid wall: $10 \mathrm{~cm}$ thickness, Brick walls with 2-side rendered and $30 \mathrm{~cm}$ thickness, Concrete slab roof. From the research Thermal Inertia of masonry case study of interlocking block, clay brick and concrete block, it summarizes that the time lag of the brick wall is 60 minutes; its thermal inertia is 67 percent, and the thermal insulation performance from thermal inertia is 45\%[14]. Table 4 shows summary of existing transparent component in windows. $\mathrm{Q}_{\mathrm{gs}}$ is calculated which Ut,Dt, SHGC, Shading Coefficient and ESR(Effective Solar Radiation) value are constants. The averaged ratio of component areas per a wall $\left(\mathrm{m}^{2}\right)$ in each elevation, between the transparent to opaque wall is $0.37: 0.63$ in a square meter.

\section{Building equipment}

To concentrate on OTTV RTTV, some variables such existing equipment- air-conditioning system and interior lighting is controlled in this research. Referred to the survey, the cooling capacity of the existing air-conditioning system of the Sirinthorn building is operated by three machines. Two chillers are mainly used, and the other is reserved (Table 6). Each chiller has a capacity of approximately 600 tons of refrigeration.

The effect from internal illuminance is also controlled in a patient room. The patients' rooms need calm and pleasant environment to recover from sickness as S. Mehrotra et al. (2015) mentioned in their research that the patient room need the least illuminance in general 30 luxs in a day and 5 luxs in a 
Waranyoo Siriwan, International Journal of Emerging Trends in Engineering Research, 8(9), September 2020, 5956 - 5965

night. Various factors to be considered in the design of lighting system for hospitals are natural lighting from window and artificial light inside[15]. The natural lighting demonstrates that patients with beds next to the window had shorter LOS (Length of Hospital Stay) than did other position in a room [16].

Typical facades and window section details

In survey, it founds the existing envelopes remain strong and durable to environment. Figure 7 explains the typical facade section of the case study and dimensions, the facade is extended 93 centimeters from an internal wall by cantilever beam structure. Specifically the section in Figure 5 and Figure 7 presents a chamfer shape at the angle of 45 degrees and the upper shading is lower than the top of window frame. The window around facades is set up at 1.10 meters from a sill to a story level. Table 7 shows summary of window detailsthe elevation, sizes, window opening nominal surface area,and their quantities divided by categories. Its shape is long and narrow along a wall.

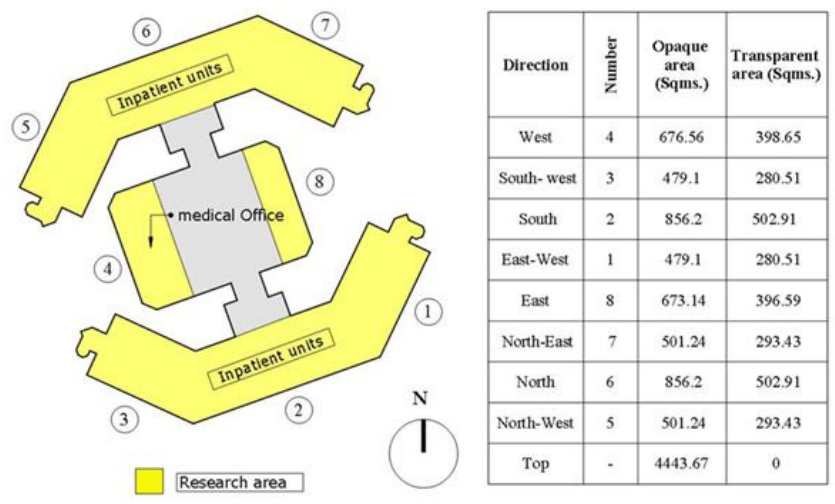

Figure 4: A typical $4^{\text {th }}-10^{\text {th }}$ floor plan of the case study and its façade area.

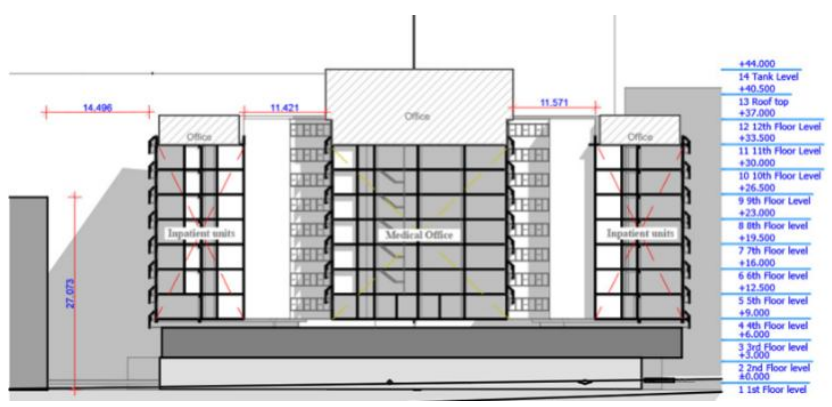

Figure 5:The building section

Table 2:Summary of the building component details

\begin{tabular}{|c|c|c|c|c|}
\hline $\begin{array}{c}\text { Compon } \\
\text { ent } \\
\text { Name }\end{array}$ & Material & Type & $\begin{array}{c}\text { Thicknes } \\
\mathrm{s}(\mathrm{m})\end{array}$ & Area $\left(\mathrm{m}^{2}\right)$ \\
\hline $\begin{array}{c}\text { Solid } \\
\text { Walls }\end{array}$ & $\begin{array}{c}10 \mathrm{~cm} \text { thickness, } \\
\text { Brick wall with } \\
\text { 2-siderendered }\end{array}$ & Opaque & 0.1 & $5,040.78$ \\
\hline Roof & $\begin{array}{c}30 \mathrm{~cm} \text { thickness, } \\
\text { Concrete slab } \\
\text { floor }\end{array}$ & Opaque & 0.3 & $2,805.34$ \\
\hline $6 \mathrm{~mm}$ \\
$\begin{array}{c}\text { Clear } \\
\text { Float } \\
\text { Glass }\end{array}$ & $\begin{array}{c}6 \text { mm thickness, } \\
\text { Clear Float } \\
\text { Glass }\end{array}$ & Transparent & 0.006 & $2,948.94$ \\
\hline
\end{tabular}

Table 3: Summary of existing opaque components in Walls by BEC.

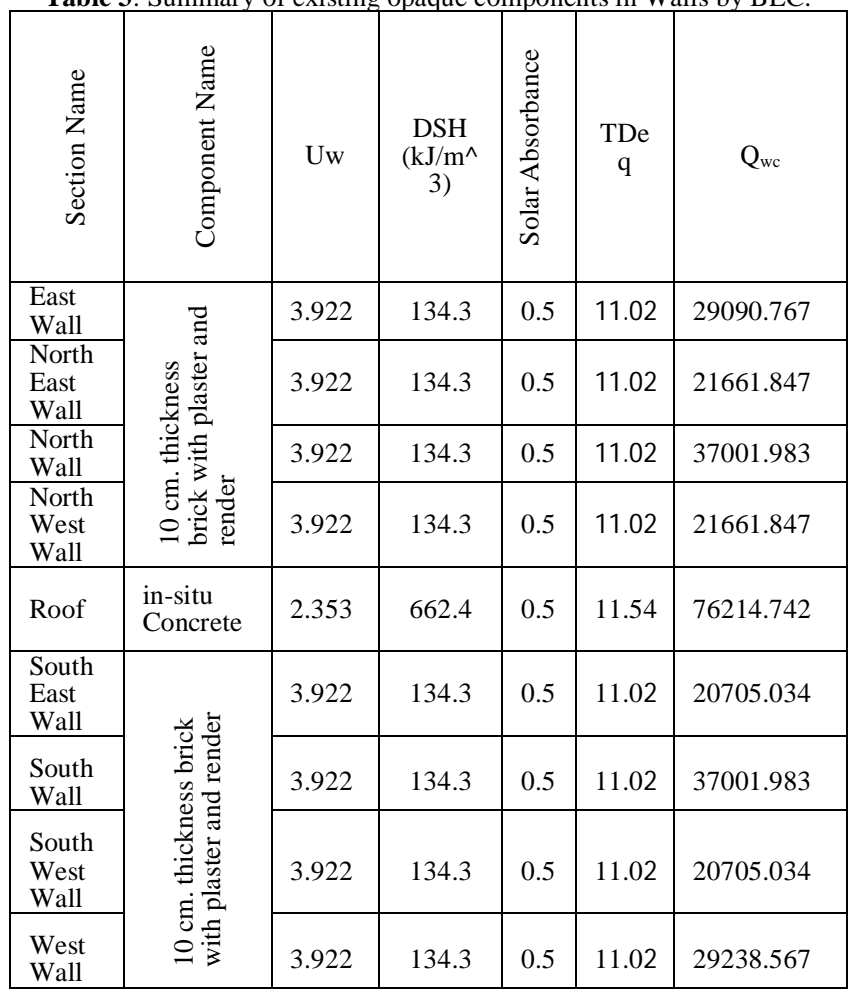

Table 4: Summary of existing transparent components in wall by BEC.

\begin{tabular}{|c|c|c|c|c|c|c|c|}
\hline $\begin{array}{l}\text { Section } \\
\text { Name }\end{array}$ & 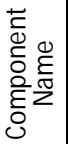 & Ut & Dt & $\underset{\mathrm{C}}{\mathrm{SHG}}$ & 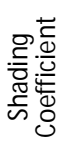 & ESR & $Q_{g s}$ \\
\hline East Wall & \multirow{8}{*}{$\begin{array}{l}\varepsilon \\
\varepsilon \\
0 \\
\mathscr{W} \\
\frac{0}{0} \\
\frac{1}{0} \\
\frac{0}{0} \\
\frac{1}{\pi} \\
\frac{0}{0}\end{array}$} & 5.74 & 3 & 0.82 & 1 & 191.44 & 69089.01 \\
\hline $\begin{array}{l}\text { North } \\
\text { East Wall }\end{array}$ & & 5.74 & 3 & 0.82 & 1 & 191.44 & 51116.46 \\
\hline $\begin{array}{l}\text { North } \\
\text { Wall }\end{array}$ & & 5.74 & 3 & 0.82 & 1 & 191.44 & 87608.56 \\
\hline $\begin{array}{l}\text { North } \\
\text { West } \\
\text { Wall }\end{array}$ & & 5.74 & 3 & 0.82 & 1 & 191.44 & 51116.46 \\
\hline $\begin{array}{l}\text { South } \\
\text { East Wall }\end{array}$ & & 5.74 & 3 & 0.82 & 1 & 191.44 & 48865.75 \\
\hline $\begin{array}{l}\text { South } \\
\text { Wall }\end{array}$ & & 5.74 & 3 & 0.82 & 1 & 191.44 & 87608.56 \\
\hline $\begin{array}{l}\text { South } \\
\text { West } \\
\text { Wall }\end{array}$ & & 5.74 & 3 & 0.82 & 1 & 191.44 & 48865.75 \\
\hline $\begin{array}{l}\text { West } \\
\text { Wall }\end{array}$ & & 5.74 & 3 & 0.82 & 1 & 191.44 & 69446.13 \\
\hline
\end{tabular}

Table 5: Summary of the cooling capacity of the existing air-conditioning system of the case study

\begin{tabular}{|c|c|c|c|c|c|c|}
\hline 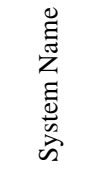 & 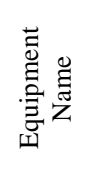 & 营 & 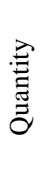 & 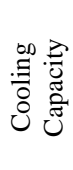 & 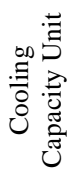 & $\begin{array}{c}\text { Power } \\
\text { Rating } \\
\text { unit }(\mathrm{KW})\end{array}$ \\
\hline Chiller & Chiller & $\begin{array}{l}\text { Water Cooled } \\
\text { Water Chiller }\end{array}$ & 2 & 600 & TR & 297 \\
\hline Chiller & $\mathrm{AHU}$ & $\begin{array}{c}\text { Air Handling } \\
\text { Unit }\end{array}$ & 1 & 450 & TR & 45 \\
\hline
\end{tabular}


Waranyoo Siriwan, International Journal of Emerging Trends in Engineering Research, 8(9), September 2020, 5956 - 5965

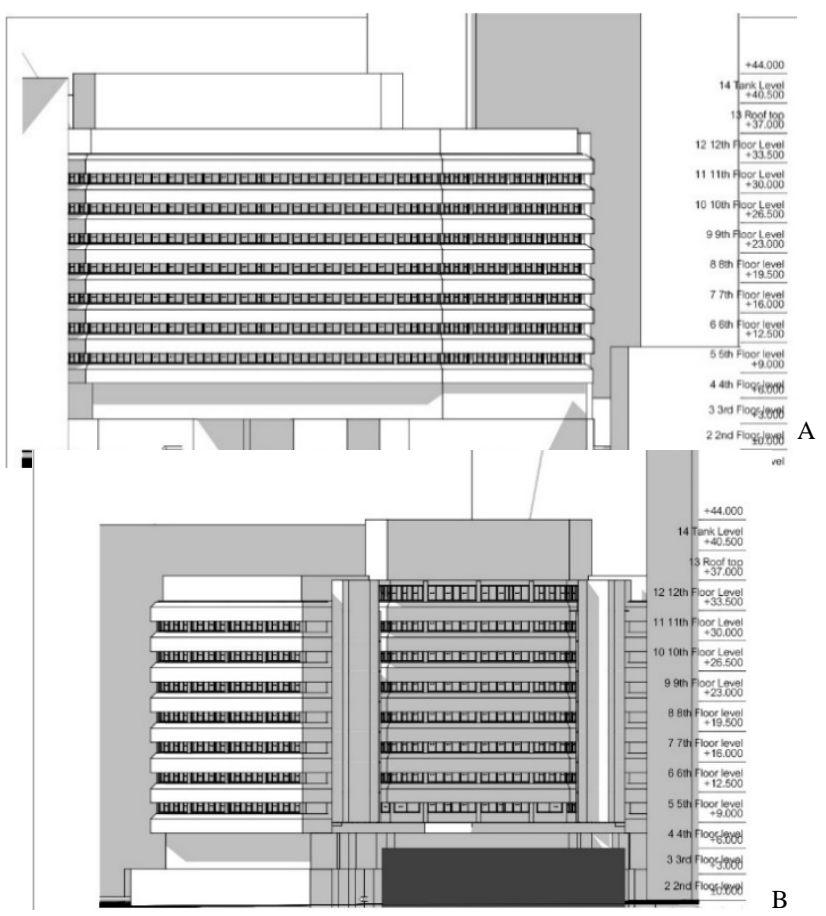

Figure 6: Effect of shadow on Building elevations at the afternoon: (A) South east elevation and (B) North east elevation

Table 6 summary of the cooling capacity of the existing air-conditioning system of the case study

\begin{tabular}{|c|c|c|c|c|c|c|}
\hline 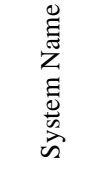 & 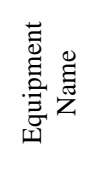 & 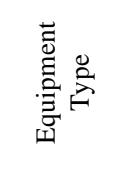 & 忐 & 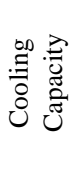 & 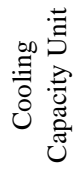 & $\begin{array}{c}\text { Power } \\
\text { Rating } \\
\text { unit(KW) }\end{array}$ \\
\hline Chiller & Chiller & $\begin{array}{c}\text { Water } \\
\text { Cooled } \\
\text { Water } \\
\text { Chiller }\end{array}$ & 2 & 600 & TR & 297 \\
\hline Chiller & $\mathrm{AHU}$ & $\begin{array}{c}\text { Air } \\
\text { Handling } \\
\text { Unit }\end{array}$ & 1 & 450 & TR & 45 \\
\hline
\end{tabular}

Note $\mathrm{TR}=\mathrm{A}$ ton of refrigeration

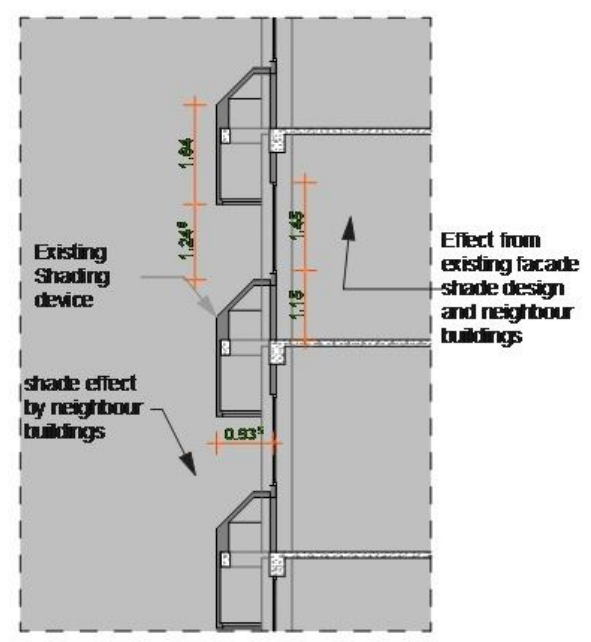

Figure 7: Typical façade section details.
Table 7: Summary of window sizes, panel areas and the quantity by categories.

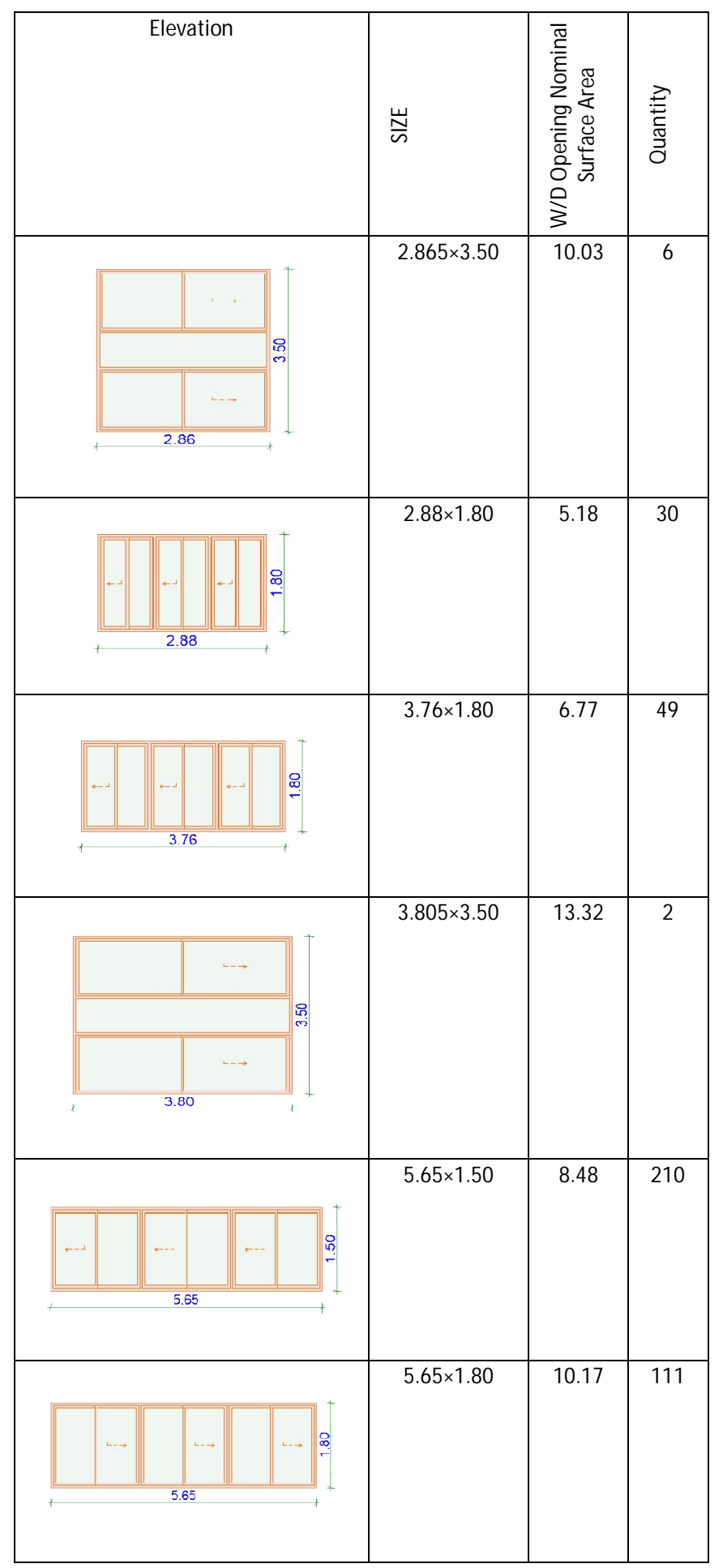

\subsection{Heritage Conservation and the cultural value}

Sirinthorn building, a large healthcare building is founded on April 16 in 1982 in the period of the early $20^{\text {th }}$ century (1932-1985 A.D.). The character of Sirinthorn as a representative of the early $20^{\text {th }}$ century of modern architecture, especially its character indicates the advancement in technology in terms of structure, for example, sun shades, outstanding reinforced concrete structure façade to conform 
Bangkok climate in that period (1982).Its cultural value is depicted the period of cultural transition and the founding of civilization that has been shaped by significant social, economic and political changes to the nation [17]. At present, The Sirinthorn is a property of Ministry of Public Health, and not yet registered by FAD as cultural heritages. However, Based on the DOCOMOMO guide, it considers that Sirinthorn shows the cultural value of the early $20^{\text {th }}$ century of modern architecture by the form of facade.

\subsection{Research method}

This research is a problem-based study on the paradigm of the heritage hospital envelope, which involves OTTV and RTTV standards. The methodology is designed to respond to all requirements and regulations with the optimum integration of refurblishment and OTTV, RTTV management by dividing survey in three parts as shown in Error! Reference source not found.. They are the first part is evaluating the internal quality of lighting and temperature in air-conditioning patients' rooms, the second part is the external assessment in cultural values in conservation, and the third part considers in a facade form and its material(opaque and transparent planes, not included a window frame detail) effecting to thermal transfer of the case study.

To approach specifically improving the building OTTV, RTTV effect on cultural view, some variables concerned n interior of patients' rooms are controlled all a day, such visual perception (from light) and thermal perception (from air-conditioners) affect each other, the higher visual comfort levels were correlated with higher thermal comfort votes [18]. The considering thermal transfer status in the third part by calculated and evaluated compared to the Thailand OTTV RTTV standard. Due to limited study period as well as acquisition of accurate information,the method of data processing by a computer software was integrally chosen of two application software types-OTTV RTTV calculation by BEC (Building Energy Code)[19][20]as in Figure 9, and building retrofit simulation by BIM (Building Information Modelling)[21] which integral of analyzing building thermal performance could help to maintain more design decisions regarding the selection of building materials [22].

BEC has evaluated the energy performance of the building envelope in compliance with Thailand's building energy code [23]. Variable surface materials are substituted by the trial and error method [24]with new materials compared with the old status to reduce building OTTV and RTTV status under the Thailand code. As BIM do illustrates building and facade form, material, site analysis and retrofit planning. The new planned refurbishment is applied for the case study to reduce OTTV RTTV and its outcome is approached to the alternative principle of OTTV, RTTV management in an envelope of a heritage hospital.

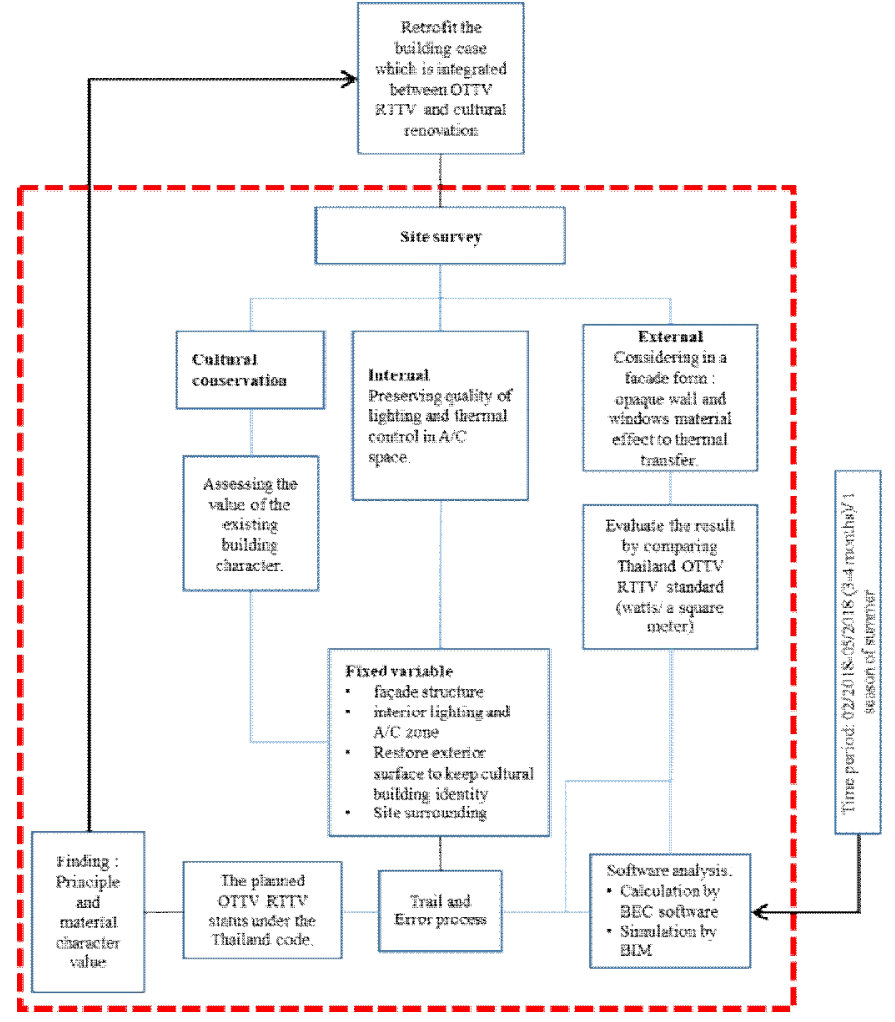

Figure 8: Research method framework.

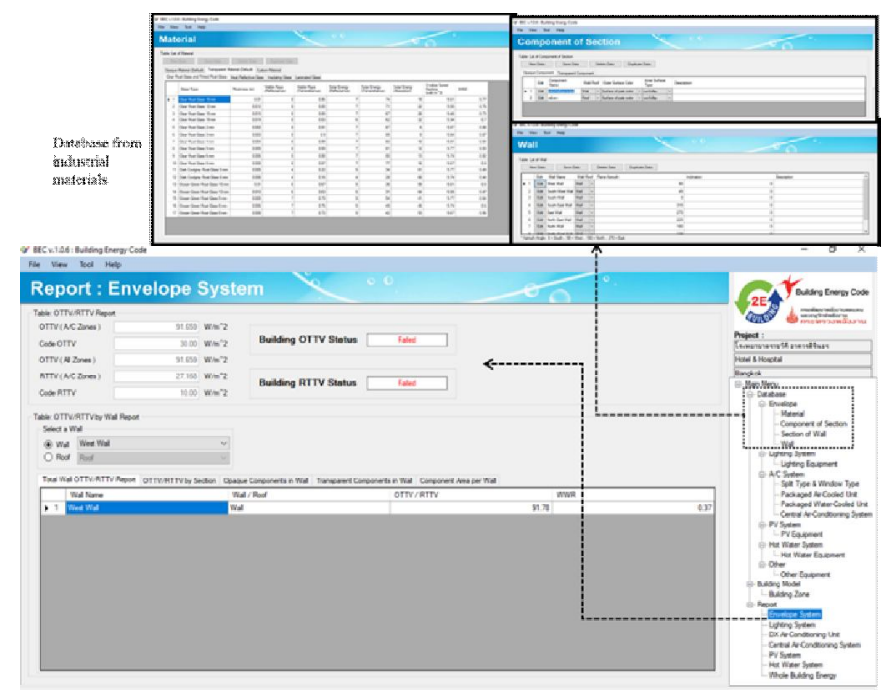

Figure 9 : Example of BEC program interface with the Sirinthorn project

\section{RESULT AND DISCUSSION}

\subsection{Building OTTV/RTTV solution and the principle}

Building OTTV/RTTV is improved by analysis the façade in its surfaces, structure, and form. After clarify the building database, initially, the numeric values of the envelope material types are inserted for calculation by the BEC with the fixed, variable, cooling capacities, and the old structural form of a facade functioning as a shading device. In the first analysis, the values are compared for two statuses: the existing and the new refurbishment, which results that the existing OTTV and RTTV statuses fail the building code 
(91.659 watts/square meter, 27.168 watts/square meter respectively) in Table 7 . These are higher than the regulation OTTV and RTTV codes for a hospital building [25], it implies that the Sirinthorn building's existing envelope cannot protect from heat transfer.

Table 8: Existing OTTV/RTTV and the status of each wall side and whole building by BEC.

\begin{tabular}{|c|c|}
\hline Wall Name & OTTV / RTTV \\
\hline East Wall & 91.78 \\
\hline North East Wall & 91.58 \\
\hline North Wall & 91.69 \\
\hline North West Wall & 91.58 \\
\hline Roof & 27.17 \\
\hline South East Wall & 91.59 \\
\hline South Wall & 91.69 \\
\hline South West Wall & 91.59 \\
\hline West Wall & 91.78 \\
\hline $\begin{array}{c}\text { Averaged Building } \\
\text { OTTV }\end{array}$ & $\begin{array}{c}\mathbf{9 1 . 6 5 9} \\
\text { Status }=\text { Fail }\end{array}$ \\
\hline $\begin{array}{c}\text { Averaged Building } \\
\text { RTTV }\end{array}$ & $\begin{array}{c}\mathbf{2 7 . 1 6 8} \\
\text { Status = Fail }\end{array}$ \\
\hline
\end{tabular}

The material analysis highlights three possible practices:section 1 is using insulation on the walls to protect against heat transfer, and replacing the existing material by using low U-value material [25], [26]for an opaque wall; And section 2is selecting a glass panel with a low SHGC (Solar Heat Gain Coefficient) [27]value for mullion glasses. SHGC is also named as the 'solar factor', it is the total solar energy transmittance factor through a glazing system separating two environments (outdoor and indoor)[25]. The other,section 3 is changing the facade form (such shading device, WWR) to increase building OTTV RTTV, the different ones generate different values [28].

During the trial and error in the framework (Figure 8) by 'testing it with observation' [29] with BEC, it implies that the important factors that affect the thermal properties of a material are especially the values of 1) thermal conductivity [26], 2) density and 3) specific heat. Moreover, the research discovered that the optimal value of the material characteristics for this hospital facade should not exceed $0.039 \mathrm{~W} / \mathrm{m} \cdot \mathrm{K}, 12 \mathrm{~kg} / \mathrm{m} 3,0.96 \mathrm{~kJ} / \mathrm{kg} \cdot \mathrm{K}$ as shown inTable 9. In the part of thermal inertia in a facade, it founds that the thicker wall from insulation increases its thermal inertia and insulation performance. An optimal feature of transparent materials such a glazing window depends on the U-Value and the SHGC values. It was also found that the transparent U-value should be higher than 2.7 and the SHGC value to be not over 0.37. After the trial-and-error process with the glass materials in the BEC, it was found that low emission (Low-E) coated glass was recommended as the optimal option for application. When this research compares various Low-E glass classes, and found that a clear color, single silver, Low-E coating on ocean green glass eight millimeters thick (8-6-8) is the optimal option (

The output from trial and error by BEC inTable 11results the building OTTV decreases from 91.659 to 29.396 watts per square meter, RTTV also dropped from 27.17 to 6.59 watts per square meter. These values after adaptation pass the standard code.

Table 10) being able to solve the OTTV problem for glass windows and walls of the Sirinthorn building.

Table 9:The maximum value of heat insulation for the opaque material

\begin{tabular}{|c|c|c|c|}
\hline Material name & $\begin{array}{c}\text { Thermal } \\
\text { Conductivity } \\
(\mathrm{W} / \mathrm{m} \cdot \mathrm{K})\end{array}$ & $\begin{array}{c}\text { Density } \\
\left(\mathrm{kg} / \mathrm{m}^{3}\right)\end{array}$ & $\begin{array}{c}\text { Specific Heat } \\
(\mathrm{kJ} / \mathrm{kg} \cdot \mathrm{K})\end{array}$ \\
\hline $\begin{array}{c}3 \text { inches. Thickness of } \\
\text { Fiberglass insulation with } \\
\text { high performance } \\
\text { abel.(Stay Cool "3Super } \\
\text { Save) }\end{array}$ & $\mathbf{0 . 0 3 9}$ & $\mathbf{1 2}$ & $\mathbf{0 . 9 6}$ \\
\hline
\end{tabular}

The output from trial and error by BEC inTable 11results the building OTTV decreases from 91.659 to 29.396 watts per square meter, RTTV also dropped from 27.17 to 6.59 watts per square meter. These values after adaptation pass the standard code.

Table 10:Examples of alternative insulation glass types

\begin{tabular}{|c|c|c|c|c|c|}
\hline Material Name & 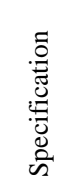 & 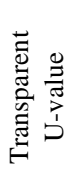 & 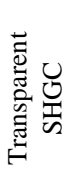 & 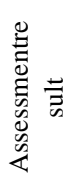 & Remark \\
\hline $\begin{array}{l}\text { Clear Color Single } \\
\text { Silver Low-E coat } \\
\text { on Ocean Green } 6 \\
\mathrm{~mm}(6-12-6)\end{array}$ & 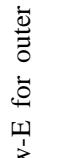 & 2 & 0.39 & No & $\begin{array}{l}\mathrm{U} \text { value }> \\
2.7, \text { SHGC } \\
\text { is over } 0.37\end{array}$ \\
\hline $\begin{array}{l}\text { Clear Color Single } \\
\text { Silver Low-E coat } \\
\text { on Ocean Green } 8 \\
\mathrm{~mm}(8-6-8)\end{array}$ & $\sum_{\bar{D}}^{\vec{\nu}}$ & 2.7 & 0.37 & Yes & Fine values \\
\hline $\begin{array}{l}\text { Clear Color Single } \\
\text { Silver Low-E coat } \\
\text { on Ocean Green } 8 \\
\mathrm{~mm}(8-12-8)\end{array}$ & $\begin{array}{l}\stackrel{0}{0} \\
\frac{0}{0} \\
0 \\
0\end{array}$ & 1.98 & 0.35 & No & $\begin{array}{c}\text { Transparent } \\
\text { U-value> } \\
2.7\end{array}$ \\
\hline $\begin{array}{l}\text { Clear Color Single } \\
\text { Silver Low-E coat } \\
\text { on Sky Blue } 6 \mathrm{~mm} \\
(6-12-6)\end{array}$ & 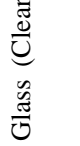 & 2.0 & 0.37 & No & $\begin{array}{c}\mathrm{U} \\
\text { value }>2.7\end{array}$ \\
\hline $\begin{array}{l}\text { Clear Color Single } \\
\text { Silver Low-E coat } \\
\text { on Sky Blue } 8 \mathrm{~mm} \\
(8-6-8)\end{array}$ & 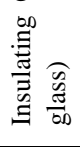 & 2.7 & 0.32 & Yes & $\begin{array}{l}\text { Best value } \\
\text { of SHGC }\end{array}$ \\
\hline
\end{tabular}

Table 11:Planned OTTV/RTTV and the status of each wall side and whole building by BEC

\begin{tabular}{|c|c|}
\hline Wall Name & OTTV / RTTV \\
\hline East Wall & 28.02 \\
\hline North East Wall & 27.86 \\
\hline North Wall & 24.30 \\
\hline North West Wall & 27.01 \\
\hline Roof & 6.59 \\
\hline South East Wall & 32.78 \\
\hline South Wall & 33.19 \\
\hline
\end{tabular}




\begin{tabular}{|c|c|}
\hline South West Wall & 32.13 \\
\hline West Wall & 32.5 \\
\hline $\begin{array}{c}\text { Averaged Building } \\
\text { OTTV }\end{array}$ & $\begin{array}{c}\mathbf{2 9 . 3 9 6} \\
\text { Status = Pass }\end{array}$ \\
\hline $\begin{array}{c}\text { Averaged Building } \\
\text { RTTV }\end{array}$ & $\mathbf{6 . 5 9}$ \\
Status = Pass \\
\hline
\end{tabular}

Refer to the results, concludes thatthe pragmatic solution for walls, roofs, windows and their panels depends on selecting the heat insulation characteristics. The opaque wall and a concrete roof part uses a composite component (the wall is an old brick wall with heat insulation material; the roof is concrete an insitu slab mounted by the heat insulation) which the recommended value (Table 9) of retrofitted insulation should be least as possible. As the window retrofits focus on a transparent material that its U-Value and SHGC value is assigned as

The output from trial and error by BEC inTable 11results the building OTTV decreases from 91.659 to 29.396 watts per square meter, RTTV also dropped from 27.17 to 6.59 watts per square meter. These values after adaptation pass the standard code.

\section{Table 10.}

These solutions are sustained to the principle of OTTV/RTTV management in a case of heritage refurbishment. In case of revitalization or reconstruction which need demolish before, the opaque component need recalculationbut the window parts can follow this pragmatic principle.However, there are some issues of the maintenance aspect. In particular, the application of the wall insulation to retrofit between an old wall and a light weigh panel (for example in Figure 11). It need improve higher quality of durability.

\subsection{Internal outcome}

The facade analysis by BIM in Figure 5, Figure 6 and Figure 7 describe the shady effect by the envelope from daylighting. It discovers that the depth of the facade (extended 93 centimeters) related to long window sizes (Table 4) is also significant factor to reduce direct daylight level to the in-patient zone all day. Also the section shape of façade which has an air cavacity inside, it reduces external heat into interior (as presented in Figure 7) . There is heat discharged due to alarge internal heat flow spreading outside the glass back orback[30]. When the results combine with the existing controlled internal environment (temperature and illuminance), it effects that the internal outcome is the risen calm and pleasant atmosphere. Consequently the inpatients receive the higher quality of rehabilitation in their rooms.

\subsection{Effect from surrounding}

The position of the research area and the building surroundings are also other important external factors which affect the OTTV and RTTV. Namely, the position of in-patient units on the 4th-10th floor are protected against the heat by the upper floors of the building (the 11th-12th floors) in Figure 10. The calculated area of the roof plane facing the sun is reduced. RTTV in the research area (6.59 watts per square meter) is lower than the whole building RTTV and the Thailand code. The tall surrounding buildings significantly affect the Sirinthorn OTTV. Figure 3shows that the surrounding buildings shade the whole case area during the day. Theoretically, the surrounding shade gives a result for the OTTV of the Sirinthorn building lower than the previous calculated value (29.40 watts per square meter). The OTTV status of the Sirinthorn building still passes the Thailand code.

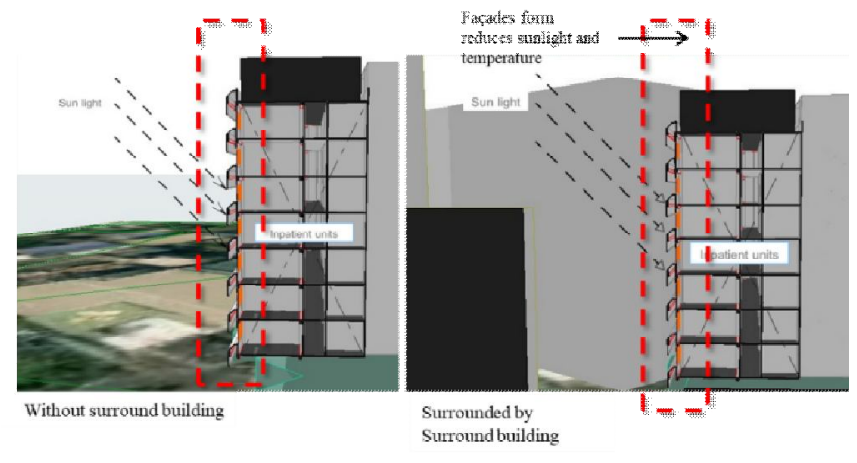

Figure 10: Shade effect from surrounding by Archicad.

\subsection{Identity and cultural perspective}

After considering practices under the specified conditions-OTTV RTTV management, the principle of heritage conservation by reviewing the strategies in DOCOMOMO international[17], and respecting the main plan of executive committees', Rajavithi hospital [31], it found section Section1 and Section2 (OTTV RTTV management, heritage conservation and the policy) can proceed. But Section3 concerns to demolition the old heritage component and renewal, in this case, the facade structure is well-functioned and valuable in a cultural aspect [17], do not require demolishing building identity of the early $20^{\text {th }}$ century modern architecture unnecessary. And demolition processes usually produce huge amount of metal,plastics, concrete and other materials as a solid waste[32].

So the optimal improvement for this case is to do integrate of Section2Error! Reference source not found., preserving the old envelope character refurbishment and its exterior finishes and adapt only the interior skins (walls and glass panel types) that increase the envelope potential in thermal transfer (Section1), as shown in Figure 11. Meanwhile the improvement is also consistent with the existing theory of keeping minimum intervention and preservation of authenticity[7]. The conservation outcome approaches to a cultural perspective by existingthe identityof the heritage façade in the period of $20^{\text {th }}$ century architecture. Its special identity rehabilitates a historic site of the old hospital, this phenomenon engages people or hospital users remember the past of the site. 


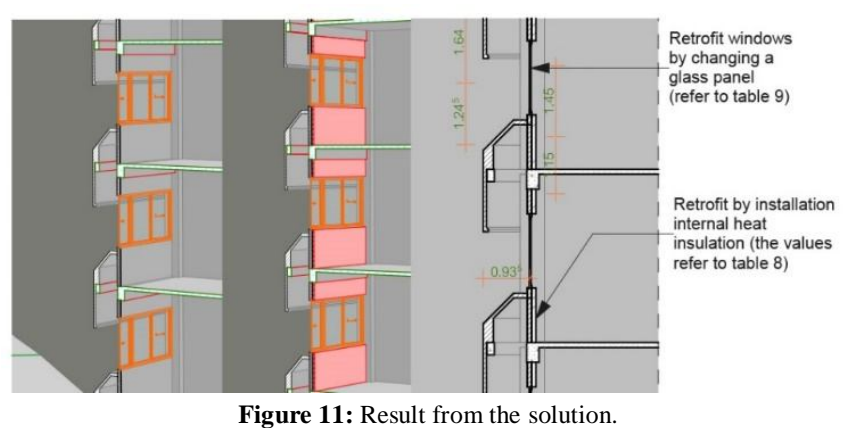

\section{CONCLUSION}

In conclusion, this researchreflects the refurbishment concept for a heritage building envelope for energy conservation, especially OTTV RTTV management through a paradigm of Sirinthorn building. The envelope is refurbished cooperatively between annexing interior insulation and old external surfaces. The result can not only reduce the OTTV and RTTV of Sirinthorn building below Thailand energy code, but also conserve the heritage character.

This paper is discussed as the pragmatic solution to control OTTV and RTTV by selecting opaque and transparent materials, the significant factors to promote energy management by reducing thermal transfer. The optimum thermal properties of the opaque materials in a wall and a roof are considered by thermal conductivity, density and specific heat; the insulation glass material are considered by U-value and SHGC. All are composed by a suitable retrofit technique to complete the renovation work. In addition, the position of case study area, surrounding building and an upper storey of inpatients' units (on the $11^{\text {th }}$ floor), isan external factor which essentially affects the building OTTV and RTTV. The surrounding buildings shade and the upper storey block the sunlight from top (Figure 10). The effect promotes a more comfortable in-patient zone for the building during the day.Absolutely the result from internal outcome cannot treat homogeneousgroup of inpatients, the same heterogeneity reflects on their motivations to do the renovation work [33].

Although the result recommends that the application of materials is a significant factor to promote energy management by reducing thermal transfer in the heritage hospital facades, itcannot reach the sustainable design stage due to other physical and aesthetic variables. The envelope also needs other architectural, engineering and construction techniques for its strengthening. Design improvements are required that take account of both energy saving and the historical architectural heritage. The expected outcome of this collaboration can be used to manage the sustainable building energy use in heritage hospitals.

\section{ACKNOWLEDGEMENT}

This research is sponsored by NRCT (National Research Council of Thailand) and Phranakorn Rajabhat University.
Finally, we thank our colleagues from Rajavithi Hospital who provided information, insight and expertise that greatly assisted the research, they may not agree of all conclusion.

\section{REFERENCES}

[1] Iain McCaig, Robyn Pender, David Pickles, Historic England, Energy Efficiency and Historic Buildings-How to Improve Energy Efficiency, E. Gold, Ed., London: Historic England, 2018.

[2] F. R. Chris Arnold, "Building Envelope Design Guide Introduction," 11 August 2016. [Online]. Available: https://www.wbdg.org/guides-specifications/building-e nvelope-design-guide/building-envelope-design-guide-i ntroduction. [Accessed 24 December 2018].

[3] Maria Isabel Abreu, Rui Oliveira, Jorge Lopes, "ENERGY-RELATED HOUSING RENOVATIONS FROM AN EVERYDAY LIFE PERSPECTIVE: LEARNING FROM PORTUGUESE HOMEOWNERS.," in ENERGY AND SUSTAINABILITY 2019, 2019.

[4] H. G. Elshimy, "Green Building as Concept of Sustainability Sustainable Strategy to Design Office Building," in 2nd International Scientific Conference on Applied Sciences and Engineering,, Dubai, 2015..

[5] Coşkun, Turgay \& Turhan, Cihan \& Arsan, Zeynep \& Gökçen Akkurt, Gülden., "The Importance of Internal Heat Gains for Building Cooling Design," Journal of Thermal Engineering, no. 3, pp. 1058-1062, $2017 .$.

[6] V. Jeyasingh, "Concept of Overall Thermal Transfer Value (OTTV) in Design of Building Envelope to Achieve Energy Efficiency.," International Journal of Thermal and Environmental Engineering., vol. 1, no. 2, pp. 75-80., 2010.

[7] Architecture Department of the University of Hong Kong, "Science Teaching Kit for Senior Secondary Curriculum- Calculation and Application of OTTV and U-value," 2012. [Online]. Available: http://minisite.proj.hkedcity.net/hkiakit/getResources.ht $\mathrm{ml}$ ?id=4061.. [Accessed 3 June 2018].

[8] Chantima Rewlay-ngoen, Krit Apinyavisit, Siripol Tongorn, Polrut Boonmee, "Strategy of Energy for Commercial Building," Science Technology and Engineering Journal(STEJ), vol. 6, no. 1, pp. 1-6, 2020.

[9] Coordinating Center for Energy Conservation Building Design, NeawTang-Buengton Nai Karn Ok-bab Akarn Anurak Palang Ngan PrasitipabSung Cheang Satapattayakum [Basic principle of Energy conservation building with architectural High performance.], Bangkok: DEDE., 2016..

[10] International Council on Monuments and Sites, "Austrlian ICOMOS.," 2013. [Online]. Available: http://portal.iphan.gov.br/uploads/ckfinder/arquivos/Th e-Burra-Charter-2013-Adopted-31_10_2013.pdf. [Accessed 13 April 2018].

[11] Fatima Rabang Alongso, Marie Rose Rabang, Ricardo L. Favis, Heritage homeowner's preservation manual-World Heritage city of Vigan, Philippine, E. E. 
Waranyoo Siriwan, International Journal of Emerging Trends in Engineering Research, 8(9), September 2020, 5956 - 5965

M. H. U. Ricardo L. Favis, Ed., Vigan: UNESCO Bangkok, 2010, pp. 18-19.

[12] N. Noisangiam, "The identity of Modern Architectural Patterns in Songkhla Old Town:.," Kasem Bundit Journal, vol. 19, no. Special edition, pp. 61-73, 2018.

[13] Osama A.El-Enein, Ghada El Rayes, Marwa Mostafa, Mohammad M. Refaey, "Energy Efficiency in Historic Buildings: a Strategy to Increase the Sustainability of the Built Environment," PORT SAID ENGINEERING RESEARCH JOURNAL, vol. 19, no. 1, pp. 31-41, March 2015.

[14] I. Phannikul, "THERMAL INERTIA OF MASONRY CASE STUDY OF INTERLOCKING BLOCK, CLAY BRICK AND CONCRETE BLOCK .," in The 14th convention of civil engineer., Nakorn Rachaseema, 2009.

[15] Sameer Mehrotra, Sunil Basukala, Shiva Devarakonda, "Effective Lighting Design Standards Impacting Patient Care: A Systems Approach," Journal of Biosciences and Medicines, vol. 3, no. 11, pp. 54-61, 2015.

[16] Man Young Park, Choul-Gyun Chai, Hae-Kyung Lee, Hani Moon, and Jai Sung Noh, "The Effects of Natural Daylight on Length of Hospital Stay," Environmental health Insight, vol. 12, no. 1-7, 2018.

[17] Suphawadee Ratanamart, Noppawan Ratanamart, "The Sustainability and Justice of the Conservation of Modern Architecture in Thailand," in The Asian Conference on Sustainability, Energy \& the Environment 2016, Kobe, 2016.

[18] Marije te Kulve, Luc Schlangen, Wouter van Marken Lichtenbelt, "Interactions between the perception of light and temperature," Indoor Air, pp. 881-891, 16 August 2018.

[19] Department of Alternative Energy Development and Energy Conservation, Khumue Kan Chai ngan Prokraem BEC V1.0.6 [The manual guideline for Building Energy Code v.1.06.]., Bangkok: Department of Alternative Enrgy Development and Energy Conservation.., 2016.

[20] Pathomthat Chiradeja , Atthapol Ngaopitakkul, "Energy and Economic Analysis of Tropical Building Envelope Material in Compliance with Thailand's Building Energy Code," Sustainability, vol. 11, no. 6872, pp. 1-23, 3 December 2019.

[21] Raimar J. Scherer, Peter Katranuschkov, "BIMification: How to create and use BIM for retrofitting," Advanced Engineering Informatics, vol. 38, pp. 54-66, October 2018.

[22] Fatima Abass, Lokman Hakim Ismail, Izudinshah Abd Wahab, Ahmed Elgadi, Hussein Onn Malaysia, Parit Raja, Batu Pahat., "Development of a Model for OTTV and RTTV based on BIMVPL to Optimize the Envelope Thermal Performance Development of a Model for OTTV and RTTV based on BIM- VPL to Optimize the Envelope Thermal Performance," in The 2nd Global Congress on Construction, Material and Structural Engineering: IOP Conference Series Materials Science and Engineering., :, 2020.

[23] Dimitrios Bikas, Panagiotis Chastas, "The Effect of the U Value in the Energy Performance of Residential," JOURNAL OF SUSTAINABLE ARCHITECTURE AND CIVIL ENGINEERING, vol. 1, no. 6, pp. 58-65, 2014.

[24] C. Muthuri, "Mathematical Models.," in Graduate Environmental and Agricultural Research (GEAR): A Guide to Effective and Relevant Graduate Research in Africa., K. C. R. A. E. Muir-Leresche, Ed., 2009., pp. 231-241..

[25] Tomás Baenas, Maider Machado, "On the analytical calculation of the solar heat gain coefficient of a BIPV module.," Energy and Buildings., no. 151, pp. 146-157., 2016.

[26] Zahra Pezeshki, Ali Soleimani, Ahmad Darabi, Sayyed Majid Mazinani, "Thermal transport in: Building materials," Construction and Building Materials, vol. 181, pp. 238-252, 2018.

[27] A. Lymath, "What is a U-value? Heat loss, thermal mass and online calculators explained.," 1 February 2015. [Online].

Available: https://www.thenbs.com/knowledge/what-is-a-u-valueheat-loss-thermal-mass-and-online-calculators-explaine d.. [Accessed 20 March 2018.].

[28] Ahmad Sanusi Hassan, Muhammad Hafeez Abdul Nasir, "Analysis on the OTTV of Modern-Style Apartment Facades in Bandar Sri Permaisuri, Kuala Lumpur.," SCIENCE \& TECHNOLOGY, vol. 25 , no. S, pp. 215 226, 2017.

[29] M. S. Al-Homoud, "Computer-aided building energy analysis techniques.," Building and Environment., vol. 36, no. 4, pp. 421-433., May 2001..

[30] Eko Julianto , Waluyo Adi Siswanto, Marwan Effendy, "Characteristics of Temperature changes and Stress of Float Glass under Heat Radiation.," International Journal of Emerging Trends in Engineering Research, vol. 7, no. 9, pp. 228-233, 2019.

[31] The committees of Developing Sirinthorn Building, Rajavithee Hospital, "Minutes of Meeting. Monthly Report.," Rajavithee Hospital, Bangkok, $2017 .$.

[32] A. Awad, "Guidelines for Civil Structures Demolition Method Selection to Enhance Environmental Protection.," International Journal of Emerging Trends in Engineering Research, vol. 8, no. 2, pp. 307-313, 2020.

[33] Giangiacomo Bravo, Georgios Pardalis, Krushna Mahapatra, Brijesh Mainali, "Physical vs. Aesthetic Renovations: Learning from," Buildings, vol. 9, no. 12, p. 15, 2019. 